\title{
The effect of environmental temperature on prandial changes in leucocyte sodium transport in man
}

\author{
BY L. L. NG ${ }^{1}$ AND T. D. R. HOCKADAY ${ }^{2 *}$ \\ ${ }^{1}$ Department of Clinical Pharmacology, ${ }^{2}$ Sheikh Rashid Diabetes Unit, Radcliffe Infirmary, \\ Oxford $O X 26 H E$
}

(Received 30 December 1988 - Accepted 8 June 1989)

\begin{abstract}
Cellular sodium transport via the $\mathrm{Na}^{+}, \mathrm{K}^{+}$-ATPase contributes significantly to daily energy expenditure. The effect of a meal on leucocyte $\mathrm{Na}^{+}$transport and intracellular electrolytes was therefore investigated in lean normal subjects at room temperatures of $23^{\circ}$ and $33^{\circ}$, to determine if the Na pump responds to the need for thermogenesis. In the fasting state, the ouabain-sensitive efflux rate which reflects active $\mathrm{Na}^{+}$ transport, and the intracellular electrolytes were similar. At $2 \mathrm{~h}$ after eating a $4.2 \mathrm{MJ}$ (1000 kcal) meal, the ouabain-sensitive efflux rate constant rose when the room temperature was $23^{\circ}$ but not at $33^{\circ}$. The ouabain-sensitive $\mathrm{Na}^{+}$efflux rate, an index of active $\mathrm{Na}^{+}$transport, rose post-prandially at $23^{\circ}$ only. The post-prandial activation of leucocyte active $\mathrm{Na}$ efflux in normal subjects was blunted at higher environmental temperatures, when the need for thermogenesis was reduced.
\end{abstract}

ATPase: Environmental temperature: Leucocytes: Sodium transport

The maintenance of high intracellular potassium and low intracellular sodium concentrations is dependent on $\mathrm{Na}^{+}, \mathrm{K}^{+}$-ATPase, and this may contribute a variable proportion of resting energy expenditure in man (Ismail-Beigi \& Edelman, 1970; Chinet et al. 1977; Swaminathan et al. 1982). The thermic effect of food and exercise constitutes the remainder of total daily energy expenditure (James \& Trayhurn, 1976). Previously, we reported that there was a post-prandial activation of leucocyte active $\mathrm{Na}$ efflux in lean humans that was reduced in obesity $(\mathrm{Ng}$ et al. 1987), and proposed that this may be due to the insulin insensitivity of the obese. If $\mathrm{Na}$ transport contributes to dietary thermogenesis, its response to a meal may depend on environmental temperature, for at higher temperatures, the need for thermogenesis would be reduced (Dauncey, 1981) and there may be less activation of active $\mathrm{Na}$ efflux post-prandially. In the present study, the effect of a meal on leucocyte $\mathrm{Na}^{+}$ transport and electrolyte content was, therefore, studied in a group of lean, normal weight humans at two different environmental temperatures, $23^{\circ}$ and $33^{\circ}$, to examine the dependency of the fasting $\mathrm{Na}^{+}$pump activity and its response post-prandially on the ambient temperature.

\section{SUBJECTS AND METHODS}

Materials

Tissue culture medium (TC199) was obtained from Wellcome Diagnostics, Beckenham, Kent, ${ }^{22} \mathrm{Na}$ from Amersham International plc, Amersham, Bucks and ouabain from the Sigma Chemical Co, Poole, Dorset. All other chemicals were purchased from BDH Chemicals Ltd, Poole, Dorset.

\section{Subjects}

Ten lean, normal weight subjects (six males, four females) were studied. Their mean age was 47.5 (SE $4 \cdot 1$ ) years and mean body mass index (weight/ height ${ }^{2}$ ) was $22.4(\mathrm{SE} 0.5) \mathrm{kg} / \mathrm{m}^{2}$. All 
were normotensive and euthyroid, and had no endocrine, metabolic or electrolyte disorders. None were on any medication including the oral contraceptive pill. The study was approved by the Oxford ethics committee.

Subjects arrived at the temperature-controlled laboratory after an overnight fast. The temperature was set at $23^{\circ}$ or $33^{\circ}$, and the order of tests on the same subject was randomized. All subjects were lightly clothed in cotton vests and shorts during the studies at both temperatures. A venous cannula was sited and they rested for $1 \mathrm{~h}$ at the experimental temperature before any blood sampling. Blood $(40 \mathrm{ml})$ was taken from fasting subjects for plasma insulin, glucose, non-esterified fatty acids, $\mathrm{Na}^{+}, \mathrm{K}^{+}$and leucocyte studies.

A $4 \cdot 2 \mathrm{MJ}(1000 \mathrm{kcal})$ test meal composed of $(\mathrm{g} / \mathrm{kg}) 150$ protein, 300 fat and 550 carbohydrate was eaten within $15 \mathrm{~min}$. Blood samples were withdrawn half-hourly, and at $2 \mathrm{~h}$ leucocyte $\mathrm{Na}^{+}$transport studies were repeated. After 1 week, the same subject was retested with a similar meal at a different room temperature.

\section{Leucocyte studies}

The leucocytes were isolated by dextran sedimentation as described previously $(\mathrm{Ng}$ et al. 1987). Cells were loaded with ${ }^{22} \mathrm{Na}$ in TC199 (final specific activity $1110 \mathrm{MBq} / \mathrm{l}$ ) at $37^{\circ}$ for $0.5 \mathrm{~h}$. The leucocytes were then washed once in $20 \mathrm{ml} \mathrm{TC199}$, a procedure that removes $99 \%$ of the extracellular ${ }^{22} \mathrm{Na} .{ }^{22} \mathrm{Na}$ efflux was then studied in TC199 at $37^{\circ}$ determined over $20 \mathrm{~min}$ in the presence and absence of ouabain ( $\mathrm{Ng}$ et al. 1987). Efflux rate constants for $\mathrm{Na}(\mathrm{ERC} ; / \mathrm{h})$ were determined by plotting $\log _{\mathrm{e}}$ cellular radioactivity $v$, time, all determinations having regression coefficients greater than 0.99 . The ouabain-sensitive ERC or the fractional turnover rate of intracellular ${ }^{22} \mathrm{Na}$, represents the active component of $\mathrm{Na}$ efflux due to the $\mathrm{Na}$ pump, and was calculated as the difference between total and ouabaininsensitive ERC. The coefficient of variation for the ouabain-sensitive ERC in the same subject on different days was $7 \%$.

The other half of the leucocyte pellet was used for determination of intracellular $\mathrm{Na}$ and $\mathrm{K}$ and was treated identically and concurrently as the half used for ${ }^{22} \mathrm{Na}$ efflux studies so that intracellular electrolyte composition would be similar. The leucocytes were incubated in $\mathrm{TC} 199$ at $37^{\circ}$ for $0.5 \mathrm{~h}$ before centrifuging the cells down and washing them three times in cold $\left(4^{\circ}\right)$ isotonic magnesium chloride buffer $\left(\mathrm{MgCl}_{2} 95 \mathrm{mmol} / \mathrm{l}\right.$, Tris base $5 \mathrm{mmol} / \mathrm{l}, \mathrm{pH}$ 7.4). This $0.5 \mathrm{~h}$ incubation in TC199 allowed the intracellular electrolyte composition to stabilize, for cells isolated by dextran sedimentation at room temperature initially have a high intracellular $\mathrm{Na}$ content which falls after $0.5 \mathrm{~h}$ at $37^{\circ}$ (Simon, 1989). The dry weight of the pellets was determined by heating them in an oven at $80^{\circ}$ for $24 \mathrm{~h}$. Nitric acid $(1 \mathrm{~mol} / \mathrm{l})$ was used to extract the dried pellets, and $\mathrm{Na}$ and $\mathrm{K}$ measured by flame photometry ( $\mathrm{Ng}$ et al. 1987). The coefficients of variation for intracellular $\mathrm{Na}$ and $\mathrm{K}$ were 12 and $10 \%$ respectively. $\mathrm{Na}$ efflux rates (expressed as $\mathrm{mmol} / \mathrm{kg}$ dry weight per $\mathrm{h}$ ) were calculated as follows:

$$
\mathrm{Na} \text { efflux rate }={ }^{22} \mathrm{Na} \text { ERC } \times \text { intracellular } \mathrm{Na} .
$$

The ouabain-sensitive efflux rate is a measure of actual flux of $\mathrm{Na}$ through the cellular $\mathrm{Na}$ pump.

\section{Other assays}

Plasma insulin was measured by radioimmunoassay, glucose by a glucose oxidase ( $E C$ 1.1.3.4) method and non-esterified fatty acid by the acyl-CoA synthetase (EC 6.2.1.3) method (Shimizu et al. 1979). Electrolytes were measured on a flame photometer. 


\section{Statistics}

Leucocyte values at the two different temperatures were compared with a paired Student's $t$ test using the Oxstat statistics package (Microsoft Ltd, Reading, Berks) as intracellular $\mathrm{Na}, \mathrm{ERC}$ and efflux rates show a Gaussian distribution ( $\mathrm{Ng}$ et al. 1987). Plasma glucose, insulin, $\mathrm{Na}, \mathrm{K}$, and non-esterified fatty acid concentrations at the two different temperatures were analysed on the Oxford University VAX cluster, using the Statistical Package for the Social Sciences (Microsoft Ltd). A two-factor repeated measures design for analysis of variance was used with temperature and time as within-subject factors. Means with their standard errors are reported, and $P$ values are two tailed and considered significant if $P<0.05$.

\section{RESULTS}

The fasting intracellular $\mathrm{K}$ and $\mathrm{Na}$ concentrations were similar at the two temperatures (Table 1). At $2 \mathrm{~h}$ post-prandially, there was a significant rise in both total and ouabainsensitive ERC at $23^{\circ}$ (Table 1). In the same subjects, the same meal at $33^{\circ}$ failed to raise total, ouabain-sensitive and ouabain-insensitive ERC significantly (Table 1). However, intracellular $\mathrm{Na}$ rose post-prandially by about the same amount at both temperatures (Table 1). When the total, ouabain-insensitive and ouabain-sensitive $\mathrm{Na}^{+}$efflux rates were calculated, the fasting ouabain-insensitive efflux rates were similar at $33^{\circ}$ and $23^{\circ}$ (Table 1). The total and ouabain-sensitive efflux rates at $33^{\circ}$ were higher than those at $23^{\circ}$, but these differences did not reach conventional levels of statistical significance. However, there was a significant post-prandial rise in the total and ouabain-sensitive efflux rates at $23^{\circ}(P<$ $0 \cdot 001$, Table 1) but not at $33^{\circ}$. The post-prandial levels were the same at the two temperatures. Intracellular $\mathrm{K}$ levels were unchanged by the meal at both temperatures.

Table 2 shows that the plasma insulin, glucose and non-esterified fatty acid levels changed with time after feeding at both temperatures $(P<0.0001$, by analysis of variance). There were no significant differences in the response of plasma insulin or non-esterified fatty acid concentrations at $23^{\circ}$ or $33^{\circ}$. However, glucose levels were significantly higher at $33^{\circ}$ than $23^{\circ}(P<0.002$, by analysis of variance $)$. Plasma $\mathrm{Na}^{+}$and $\mathrm{K}^{+}$were not different at the two temperatures (Table 2).

\section{DISCUSSION}

Endothermy may depend on a 'futile' cycle of $\mathrm{Na}^{+}$entering cells and subsequently being actively expelled by the $\mathrm{Na}^{+} \mathrm{K}^{+}$-ATPase, using up ATP in the process $(\mathrm{Ng}$ et al. 1987). We have previously demonstrated a post-prandial activation of leucocyte $\mathrm{Na}^{+}$efflux via the $\mathrm{Na}$ pump in lean subjects ( $\mathrm{Ng}$ et al. 1987) and demonstrated a similar increase after intravenous infusion of insulin when plasma glucose concentration was kept normal. This stimulatory effect has also been shown for oral glucose (Ng \& Hockaday, 1987; Turaihi et al. 1988a) in normal subjects. In obesity, the fasting leucocyte Na pump activity is raised (Turaihi et al. 1987). Furthermore, the activation of cellular active $\mathrm{Na}$ efflux post-prandially or by insulin infusion in an euglycaemic clamp is much reduced in obesity, probably due to insulin resistance ( $\mathrm{Ng}$ et al. 1987 ), and this may be a possible contributor to energetic efficiency in obesity. In contrast, Turaihi et al. (1988 b) found Na pump activity in anorexia nervosa to be lowered. The $\mathrm{Na}$ pump activity is thus dependent on the subject's state of nutrition.

Dauncey (1981) had shown that resting energy expenditure was significantly higher at $22^{\circ}$ when compared with $28^{\circ}$, and that after a $2.6 \mathrm{MJ}$ liquid meal, energy expenditure may remain elevated for a longer period at $22^{\circ}$ than at $28^{\circ}$. We, therefore, investigated the effect of feeding a large meal on leucocyte active $\mathrm{Na}$ efflux at two different temperatures: (1) at 
Table 1. Leucocyte ${ }^{22} \mathrm{Na}$ efflux rate constants (ERC), intracellular electrolytes and $\mathrm{Na}^{+}$ efflux rates in ten normal subjects before and $2 \mathrm{~h}$ after $a 4.2 \mathrm{MJ}$ meal at $33^{\circ}$ and $23^{\circ}$

(Mean values with their standard errors)

\begin{tabular}{|c|c|c|c|c|c|}
\hline \multirow[t]{2}{*}{ Ambient temperature... } & & \multicolumn{2}{|c|}{$33^{\circ}$} & \multicolumn{2}{|c|}{$23^{\circ}$} \\
\hline & & Preprandial & Post-prandial & Preprandial & Post-prandial \\
\hline \multicolumn{6}{|l|}{$\operatorname{ERC}(/ h)$} \\
\hline \multirow[t]{2}{*}{ Total } & Mean & $3 \cdot 37$ & $3 \cdot 31$ & $3 \cdot 08$ & $3 \cdot 32^{* *}$ \\
\hline & SE & $0 \cdot 12$ & $0 \cdot 18$ & $0 \cdot 15$ & $0 \cdot 15$ \\
\hline \multirow[t]{2}{*}{ Ouabain-insensitive } & Mean & $0 \cdot 65$ & 0.61 & 0.68 & 0.61 \\
\hline & $\mathrm{SE}$ & 0.03 & 0.05 & $0 \cdot 06$ & 0.05 \\
\hline \multirow[t]{2}{*}{ Ouabain-sensitive } & Mean & $2 \cdot 73$ & $2 \cdot 70$ & $2 \cdot 39$ & $2 \cdot 71 * * *$ \\
\hline & $\mathrm{SE}$ & $0 \cdot 10$ & $0 \cdot 16$ & $0 \cdot 11$ & $0 \cdot 13$ \\
\hline \multicolumn{6}{|l|}{$\begin{array}{l}\text { Electrolytes (mmol } / \mathrm{kg} \\
\text { dry wt) }\end{array}$} \\
\hline \multirow[t]{2}{*}{ Intracellular $\mathrm{Na}$} & Mean & 346 & 376 & 326 & 340 \\
\hline & $\mathrm{SE}$ & 22 & 17 & 19 & 13 \\
\hline \multirow[t]{2}{*}{ Intracellular $\mathrm{K}$} & Mean & $34 \cdot 5$ & $43 \cdot 7^{*}$ & $31 \cdot 0$ & $39 \cdot 5^{* *}$ \\
\hline & SE & $3 \cdot 8$ & $4 \cdot 8$ & $3 \cdot 3$ & $2 \cdot 9$ \\
\hline \multicolumn{6}{|l|}{$\begin{array}{l}\text { Efflux rates (mmol/kg } \\
\text { dry wt per } h \text { ) }\end{array}$} \\
\hline \multirow[t]{2}{*}{ Total } & Mean & 117 & 148 & 96 & $130^{* * *}$ \\
\hline & $\mathrm{SE}$ & 15 & 21 & 12 & 10 \\
\hline \multirow[t]{2}{*}{ Ouabain-insensitive } & Mean & 22 & 26 & 21 & 24 \\
\hline & $\mathrm{SE}$ & 2 & 3 & 3 & 2 \\
\hline \multirow[t]{2}{*}{ Ouabain-sensitive } & Mean & 96 & 122 & 75 & $106^{* * *}$ \\
\hline & $S E$ & 13 & 19 & 10 & 9 \\
\hline
\end{tabular}

Mean values at $2 \mathrm{~h}$ after the meal were significantly different from pre-meal levels (Student's $t$ test): ${ }^{*} P<0.05$, ** $P<0.01$, *** $P<0-001$.

$23^{\circ}$, which is at the lower limit of the thermoneutral zone for both lean and obese subjects

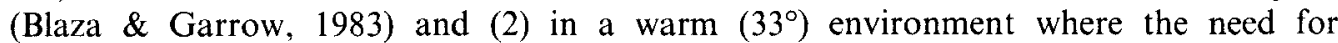
thermogenesis may be much reduced. A difference in response of the cellular $\mathrm{Na}^{+}$pump at the two different temperatures may be apparent if the $\mathrm{Na}$ pump contributes significantly to thermogenesis, as suggested by previous workers (Ismail-Beigi \& Edelman, 1970; Chinet et al. 1977; Swaminathan et al. 1982). At $23^{\circ}$, a significant post-prandial rise in the active cellular $\mathrm{Na}^{+}$efflux rate was found, whereas at $33^{\circ}$ where post-prandial heat generation would be superfluous, the meal failed to elicit this cellular $\mathrm{Na}^{+}$pump response. Therefore, the thermic effect of food attributable to the change in activity of the Na pump may be reduced at a higher ambient temperature, where a rise in Na pump activity would have been inappropriate. However, in the fasting state, the active component of cellular $\mathrm{Na}^{+}$efflux (the ouabain-sensitive efflux rate) was higher at $33^{\circ}$ than at $23^{\circ}$, though this did not reach conventional levels of statistical significance, perhaps because of the small number of subjects studied. This raised fasting active $\mathrm{Na}^{+}$efflux rate could have blunted any further prandial rise of the efflux rate at $33^{\circ}$, and may suggest that factors controlling the basal preprandial and post-prandial $\mathrm{Na}^{+}$efflux rates may differ at the two temperatures studied.

The rise in intracellular $\mathrm{Na}$ post-prandially at both ambient temperatures may be due to an increased cellular $\mathrm{Na}^{+}$influx, but this was not directly measured in the present study. The increased $\mathrm{Na}^{+}$influx could be due to the rise in plasma insulin levels, for Rosic et al. (1985) found an increased $\mathrm{Na}^{+}$influx via the $\mathrm{Na}^{+} / \mathrm{H}^{+}$antiport with secondary activation of the $\mathrm{Na}^{+}, \mathrm{K}^{+}$-ATPase in skeletal muscle after treatment with insulin. 


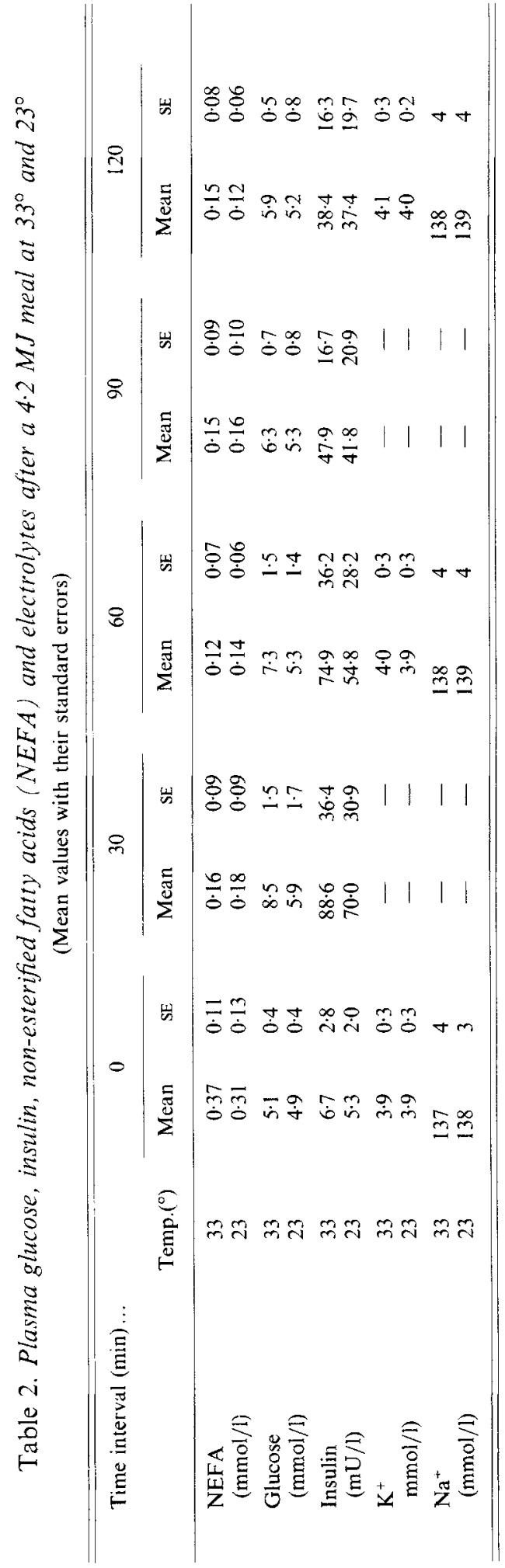


The difference in response to feeding of the leucocyte Na pump at the two temperatures was not attributable to differences in the post-prandial changes of plasma non-esterified fatty acids which are known inhibitors of $\mathrm{Na}$ transport ( $\mathrm{Ng} \&$ Hockaday, 1986, 1988). Electrolyte changes were also not contributory. However, although insulin responses were similar, the glucose levels were significantly higher at all time-points after the meals given at $33^{\circ}$ (Akanji et al. 1987). This may indicate 'arterialization' of venous blood at $33^{\circ}$ (Frayn et al. 1989), though an alternative explanation may be reduced insulin sensitivity. If the latter were true, it may explain the lack of prandial activation of the leucocyte Na pump at $33^{\circ}$, as we have previously demonstrated that the response was reduced in insulin-resistant obese subjects infused with intravenous insulin and glucose ( $\mathrm{Ng}$ et al. 1987).

In conclusion, the present study and those that examined nutritional influences on the leucocyte $\mathrm{Na}$ pump (Ng et al. 1987; Ng \& Hockaday, 1987; Turaihi et al. 1987, 1988a,b) illustrate the adaptive nature of $\mathrm{Na}^{+}, \mathrm{K}^{+}$-ATPase to changes in nutrition and ambient temperature. The post-prandial response of the cellular $\mathrm{Na}$ pump to a $4.2 \mathrm{MJ}$ meal was blunted at $33^{\circ}$ when compared with the same lean subjects at $23^{\circ}$, suggesting that this response of the Na pump to feeding may adapt to the need for thermogenesis. At present, the mechanism of this adaptation is uncertain, although one possibility is a reduced sensitivity to the action of insulin at higher environmental temperatures.

The authors are grateful to the Oxford Diabetes Trust's support of the Sheikh Rashid Diabetes Unit. L.L.N. held an MRC Training Fellowship during this work. The authors thank Mrs J. Mclean-Bushnell, Mrs S. Humphreys and Mr A. D. Hutchings for technical assistance, and Dr M. A. Bruce for help with the subjects.

\section{REFERENCES}

Akanji, A. O., Bruce, M., Frayn, K., Hockaday, T. D. R. \& Kaddaha, G. M. (1987). Oral glucose tolerance and ambient temperature in non-diabetic subjects. Diabetologia 30, 431-433.

Blaza, S. \& Garrow, J. S. (1983). Thermogenic response to temperature, exercise and food stimuli in lean and obese women, studied by $24 \mathrm{~h}$ direct calorimetry. British Journal of Nutrition $49,171-180$.

Chinet, A., Clausen, T. \& Girardier, L. (1977). Microcalorimetric determination of energy expenditure due to active sodium-potassium transport in the soleus muscle and brown adipose tissue of the rat. Journal of Physiology 265, 43-61.

Dauncey, M. J. (1981). Influence of mild cold on $24 \mathrm{~h}$ energy expenditure, resting metabolism and diet-induced thermogenesis. British Journal of Nutrition 45, 257-267.

Frayn, K. N., Whyte, P. L., Benson, H. A., Earl, D. J. \& Smith, H. A. (1989). Changes in forearm blood flow at elevated ambient temperatures and their role in the apparent impairment of glucose tolerance. Clinical Science 76, 323-328.

Ismail-Beigi, G. \& Edelman, I. S. (1970). Mechanism of thyroid calorigenesis: role of active sodium transport. Proceedings of the National Academy of Sciences, USA 67, 1071-1078.

James, W. P. T. \& Trayhurn, P. (1976). An integrated view of the metabolic and genetic basis for obesity. Lancet ii, $770-773$.

Ng, L. L., Bruce, M. A. \& Hockaday, T. D. R. (1987). Leucocyte sodium pump activity after meals or insulin in normal and obese subjects: cause for increased energetic efficiency in obesity? British Medical Journal 295, 1369-1373.

Ng, L. L. \& Hockaday, T. D. R. (1986). Non-esterified fatty acids may regulate human leucocyte sodium pump activity. Clinical Science 71, 737-742.

Ng, L. L. \& Hockaday, T. D. R. (1987). The effect of oral glucose on the leucocyte sodium pump in normal and obese subjects. Clinical Endocrinology 27, 345-353.

$\mathrm{Ng}$, L. L. \& Hockaday, T. D. R. (1988). The effect of Intralipid infusion on the human leucocyte sodium pump in vivo. British Journal of Nutrition 60, 49-55.

Rosic, N. K., Standaert, M. L. \& Pollet, R. J. (1985). The mechanism of insulin stimulation of $\left(\mathrm{Na}^{+}, \mathrm{K}^{+}\right)-\mathrm{ATPase}$ transport activity in muscle. Journal of Biological Chemistry 260, 6206-6212.

Simon, G. (1989). Is intracellular sodium increased in hypertension? Clinical Science 76, 455 461.

Shimizu, S., Inoue, K., Tani, Y. \& Yamada, H. (1979). Enzymatic microdetermination of serum free fatty acids. Analytical Biochemistry 98, 341--345. 
Swaminathan, R., Burrows, G. \& McMurray, J. (1982). Energy cost of sodium pump activity in man: an in-vivo study of metabolic rate in human subjects given digoxin. IRCS Clinical Biochemistry 10, 949.

Turaihi, K., Baron, D. N. \& Dandona, P. (1987). Increased leucocyte Na-K ATPase in obesity: reversal following weight loss. Metabolism 36, 851-855.

Turaihi, K., Baron, D. N. \& Dandona, P. (1988a). Effect of glucose intake on ${ }^{86} \mathrm{Rb}$ influx and $\left[{ }^{3} \mathrm{H}\right]$ ouabain binding. Metabolism 37, 171-174.

Turaihi, K., D'Souza, V., Wakeling, A. \& Dandona, P. (1988 b). Diminished $\left[{ }^{3} \mathrm{H}\right]$ ouabain binding and ${ }^{86} \mathrm{Rb}$ influx by leucocytes in anorexia nervosa. Metabolism 37, 486-490. 